\title{
The influence of glucagon on the concentration of triacylglycerols and cholesterol in the liver and kidney of mice
}

\author{
Jolanta Klusek', Bożena Witek', Justyna Klusek², Elżbieta Tomasik1, Agnieszka \\ Kamińska ${ }^{4}$ and Adam Kołątaj ${ }^{3}$ \\ 'Institute of Biology, Jan Kochanowski University, Kielce, Poland, 'Department of Surgery and Surgical Nursing, \\ Institute of Nursing and Obstetrics, Jan Kochanowski University of Humanities and Sciences, Kielce, Poland, ${ }^{3}$ Institute \\ of Genetics and Animal Breeding, Polish Academy of Sciences, Jastrzębiec, Wólka Kosowska, Poland, 4»Praktyka \\ Lekarsk«, Warsaw, Poland
}

\begin{abstract}
The experiment was performed to determine the effect of pharmacological doses of glucagon, administered over a period of 4 or 8 days to sexually mature male Swiss mice, on the concentration of triacylglycerols and cholesterol in the liver and kidneys of mice selected for fast rate of body weight gain and unselected ones kept on a high-protein and low-protein diet. On the basis of the results obtained it was concluded that the selection and the diet, as well as glucagon injections, were lowering the content of triacylglycerols and cholesterol in the examined organs of mice, in many cases confirmed in a statistically significant way.
\end{abstract}

Keywords: mice, glucagon, triacylglycerols, cholesterol

\section{Introduction}

Glucagon is described as an agent that mobilizes activating energy substrates of an organism in periods of increased need for them in cells, by regulating, among other things, the concentration of glucose, free fatty acids and amino acids in blood plasma (Hancock et al. 2010, Lou et al. 2011, Peyot et al. 2009, Vieira et al. 2007).

One of the main factors that determine the progress in animal breeding is selection apart from proper nutrition. Admittedly, it leads to obtaining specimens closer to genetic 
perfection and highly efficient in regards to the goal of breeding. However, they tend to have more difficulty with adapting to negative environmental conditions in comparison to unselected specimens. The topic of selection has been extensively discussed in both classic (Falconer 1960, Bateman 1971) and recent literature (Åberg et al. 2000, Coleman et al. 2009, Klusek et al. 2011, Książek \& Konarzewski 2012, Witek et al. 2007).

However, there have been no reports of a scope of reaction to glucagon in animals selected for body weight gain fed with low-protein feed. Therefore, the goal of this work is to observe the influence of administering pharmacological doses of this hormone on the concentration of triacylglycerol and cholesterol in the liver and kidneys of mice as a model species of a laboratory animal kept on a diet with standard protein content and on a diet with its significant deficiency, which is still common in household animal breeding.

\section{Material and methods}

The research was conducted on 60 sexually mature Swiss male mice at the age of 6-8 weeks taken from the breeding farm of the Institute of Genetics and Animal Breeding of the Polish Academy of Sciences in Jastrzębiec. These mice were selected over 25 generations for fast rate of body weight gain and weighing $35 \pm 2.5 \mathrm{~g}$. Furthermore, 60 sexually mature unselected males were treated as a control group. These mice were weighing $20 \pm 1.5 \mathrm{~g}$ and came from random parents. The selection was based on matching parent specimens male and female of the highest body weight, taken from the initial population.

The animals were kept under standard breeding conditions in a room on a mice farm with temperature of $21-22^{\circ} \mathrm{C}$ and with natural photoperiodism. They had constant access to water and were given a professional veterinary care.

When the animals reached the age of 6 weeks, they were taken from their mothers and fed with granulated feed with diversified protein content for two weeks according to the data provided in Table 1. The laboratory analysis has been made in the Institute of Physiology and Nutrition of the Polish Academy of Sciences in Jablonna near Warsaw, Poland.

Table 1

Per cent content of components in the diets of experimental animals (according to AOAC 2001)

\begin{tabular}{lcc}
\hline Item & Per cent in diet protein $10 \%$ & Per cent in diet protein $16 \%$ \\
\hline Premix LSM & 1.02 & 1.01 \\
Salt & 0.29 & 0.29 \\
Chalk & 1.65 & 1.64 \\
Phosphates & 0.97 & 0.97 \\
Milk powder & 4.52 & 5.80 \\
Soybean meal & 1.94 & 10.14 \\
Corn meal & 89.32 & 64.71 \\
Cereal germs & 0.29 & 15.44 \\
Leucine, \% in protein & 11.6 & 8.9 \\
Lysine, \% in protein & 3.9 & 4.7 \\
Energy (brutto), MJ/kg in diets & $\sim 13.47$ & $\sim 14.04$ \\
Exact contents, \% of protein in diets & 10.38 & 15.51 \\
\hline
\end{tabular}


The animals in control groups (I, IV, VII, X) were administered $250 \mu \mathrm{l}$ of $0.9 \% \mathrm{NaCl}$ solution intraperitoneally twice a day (8:00 and 20:00) and the specimens from test groups (II, III, V, $\mathrm{VI}, \mathrm{VIII}, \mathrm{IX}, \mathrm{XI}, \mathrm{XII}$ ) were administered glucagon analogically with a dose of $15 \mu \mathrm{g} / \mathrm{kg}$ of body weight in a volume of $250 \mu$ lover 4 or 8 days, respectively.

Table 2

Arrangement of test groups

\begin{tabular}{|c|c|c|c|}
\hline \multirow[t]{2}{*}{ Diet } & \multirow[t]{2}{*}{$\mathrm{n}$} & \multicolumn{2}{|c|}{ Group } \\
\hline & & Selected mice & Unselected mice \\
\hline \multirow[t]{3}{*}{$16 \%$ protein } & 10 & I control & IV control \\
\hline & 10 & Il glucagon 4 days & V glucagon 4 days \\
\hline & 10 & III glucagon 8 days & VI glucagon 8 days \\
\hline \multirow[t]{3}{*}{$10 \%$ protein } & 10 & VII control & $X$ control \\
\hline & 10 & VIII glucagon 4 days & $\mathrm{XI}$ glucagon 4 days \\
\hline & 10 & IX glucagon 8 days & XII glucagon 8 days \\
\hline
\end{tabular}

After the conclusion of the experiment, two hours after administering the last injection of either glucagon or $0.9 \% \mathrm{NaCl}$ solution, the animals were decapitated after a short anaesthesia with vetbutal. Immediately after exsanguinating, liver and kidneys were sampled. The liver was subjected to perfusion with $0.9 \% \mathrm{NaCl}$ solution cooled to $+4^{\circ} \mathrm{C}$ and, like kidneys, was suspended in $0.1 \mathrm{M}$ phosphate buffer ( $\mathrm{pH}$ 7.4) containing $10 \mathrm{mM}$ EDTA. Tissues prepared in this way were homogenized in Potter-Elvehjem low-speed glass homogenizer at $200 \mathrm{rpm}$ with Teflon piston placed in a container with crushed ice. Liver and kidney homogenates obtained this way were centrifuged for $10 \mathrm{~min}$ at $12000 \mathrm{rpm}$ at a temperature of approximately $+4^{\circ} \mathrm{C}$ in a Janetzki K-24 centrifuge.

The concentration of triacylglycerols in the supernatants of the liver and kidneys was determined with tests by Alpha Diagnostic (Warsaw, Poland) and the cholesterol level was determined with tests by Biochemtest (Gliwice, Poland). The results were expressed in $\mu \mathrm{mol} / \mathrm{g}$ of tissue.

Analysis of variance connected with the effects of experimental factors on the concentration of triacylglycerols and cholesterol in the liver and kidney of mice was conducted with the use of analysis of variance and t-test for each organ and each diet separately according to the following equations:

$$
y_{i j k l}=D_{i}+G_{j}+T_{k}+e_{i j k l}
$$

where $D_{i}$ is the protein level in the diet, $G_{j}$ are the genetic groups (selected and unselected animals), $T_{k}$ is the time of the glucagon injections and $e_{i j k l}$ is the error.

$$
y_{i j k l}=O_{i}+G_{j}+T_{k}+e_{i j k l}
$$

where $O_{i}$ is the organ (liver, kidney), $G_{i}$ are the genetic groups (selected and unselected animals), $T_{k}$ is the time of the glucagon injections and $e_{i j k l}$ is the error.

The experiment was approved by the Ethical Commission of the Institute of Genetics and Animal Breeding and the Polish Academy of Sciences (Jastrzębiec, Poland). 


\section{Results}

The data from Table 3 indicate that the concentration of triacylglycerols was significantly different in both genetic groups of the animals examined as well as in those kept on a diet with $16 \%$ protein content and those kept on a diet with $10 \%$ protein content. The selected animals on a diet with $16 \%$ protein content showed higher concentrations in the liver ( 25.5 vs. 19.9) and kidney (18.3 vs. 11.4). The same could be observed in animals on a diet with lowprotein (liver: 26.7 vs. 19.3; kidney: 17.5 vs. 15.2).

Table 3

Concentration of triacylglycerols and cholesterol $(\overline{\mathrm{x}} \pm \mathrm{SD})$ in the liver and kidney $(\mu \mathrm{mol} / \mathrm{g}$ tissue) of control mice after $0.9 \% \mathrm{NaCl}$ injection

\begin{tabular}{lcccc}
\hline Group & \multicolumn{2}{c}{ Selected mice } & \multicolumn{2}{c}{ Unselected mice } \\
& $\begin{array}{c}\text { Liver } \\
\overline{\mathrm{x}} \pm \mathrm{SD}\end{array}$ & $\begin{array}{c}\text { Kidney } \\
\overline{\mathrm{x}} \pm \mathrm{SD}\end{array}$ & $\begin{array}{c}\text { Liver } \\
\overline{\mathrm{x}} \pm \mathrm{SD}\end{array}$ & $\begin{array}{c}\text { Kidney } \\
\overline{\mathrm{x}} \pm \mathrm{SD}\end{array}$ \\
\hline Triacylglycerols & & & & \\
$\quad$ Diet 16\% protein & $25.5 \pm 3.5^{\mathrm{a}}$ & $18.3 \pm 3.7^{\mathrm{b}}$ & $19.9 \pm 4.4^{\mathrm{a}}$ & $11.4^{\mathrm{a}} \pm 4.3^{\mathrm{b}, \mathrm{e}}$ \\
$\quad \begin{array}{c}\text { Diet 10\% protein } \\
\text { Cholesterol }\end{array}$ & $26.7 \pm 4.2^{\mathrm{c}}$ & $17.5 \pm 3.1^{\mathrm{d}}$ & $19.3 \pm 3.3^{\mathrm{c}}$ & $15.2 \pm 3.1^{\mathrm{d}, \mathrm{e}}$ \\
Diet 16\% protein & & & & \\
$\quad$ Diet 10\% protein & $4.1 \pm 0.7$ & $3.8 \pm 0.1^{\mathrm{a}}$ & $4.5 \pm 1.4$ & $3.9 \pm 0.4^{\mathrm{b}}$ \\
\hline
\end{tabular}

$\mathrm{a}-\mathrm{a}, \mathrm{b}-\mathrm{b}, \mathrm{c}, \mathrm{c}, \mathrm{d}-\mathrm{d}, \mathrm{e}-\mathrm{e}$ Means with similar superscripts differ significantly $(P<0.05)$.

The data from Table 3 also show that the concentration of triacylglycerols in the liver and kidneys of mice from selected control groups $(0.9 \% \mathrm{NaCl})$ fed with both $16 \%$ and $10 \%$ protein content was very similar $(25.5,26.7 ; 18.3,17.5)$. The same was seen in the liver of unselected mice $(19.9,19.3)$, whereas in kidneys of unselected mice the content of triacylglycerols was clearly different for both groups $(11.4,15.2)$.

The level of cholesterol in the liver and kidney of control mice did not differ significantly between groups of selected and unselected animals fed a $16 \%$ protein diet (4.1 vs. 4.5; 3.8 vs. 3.9). However, selected animals fed a low-protein diet revealed significantly higher cholesterol levels both in the liver (4.9 vs. 3.9) and the kidney (4.8 vs. 3.1).

As the data in Table 3 show, the concentrations of cholesterol in the liver of selected and unselected control groups of mice kept on a diet with $16 \%$ and $10 \%$ protein content were similar (4.1 vs. $4.9 ; 4.5$ vs. 3.9 ), whereas the kidney showed significant differences in the concentration of the examined indicator (3.8 vs. 4.8 for selected mice; 3.9 vs. 3.1 for unselected mice).

The injections of glucagon (Table 4) administered over a period of 4 and 8 days caused a significant reduction of the triacylglycerol level in the liver of selected mice that were on a diet with $16 \%$ protein content (18.8 vs. $25.5 ; 20.1$ vs. 25.5$)$. No statistically confirmed changes were observed in the kidney. In the same genetic group of mice kept on a low-protein diet also a significant reduction of examined levels was observed in the liver of mice that were administered glucagon over 8 days (19.7 vs. 26.7) as well as in the kidney after 4 days (12.9 vs. 17.5 ) and 8 days (13.6 vs. 17.5) of the experiment.

In unselected mice kept on a diet with $16 \%$ protein content, the injections of glucagon did not cause any significant changes in the level of triacylglycerols in the liver and kidney. 
Table 4

Concentration of triacylgycerols $(\overline{\mathrm{x}} \pm \mathrm{SD})$ in the liver and the kidney ( $\mu \mathrm{mol} / \mathrm{g}$ tissue) of experimental and control mice maintained on diets with $10 \%$ and $16 \%$ of protein after glucagon injections

\begin{tabular}{|c|c|c|c|c|}
\hline \multirow[t]{2}{*}{ Group $(n=10)$} & \multicolumn{2}{|c|}{ Selected mice } & \multicolumn{2}{|c|}{ Unselected mice } \\
\hline & $\begin{array}{l}\text { Liver } \\
\bar{x}+S D\end{array}$ & $\begin{array}{c}\text { Kidney } \\
\bar{x}+S D\end{array}$ & $\begin{array}{l}\text { Liver } \\
\bar{x}+S D\end{array}$ & $\begin{array}{c}\text { Kidney } \\
\bar{x}+S D\end{array}$ \\
\hline \multicolumn{5}{|l|}{ Diet $16 \%$ protein } \\
\hline Control & $25.5 \pm 3.5^{\mathrm{a}, \mathrm{b}}$ & $18.3 \pm 3.7$ & $19.9 \pm 4.4$ & $11.4 \pm 4.3$ \\
\hline Glucagon 4 days & $18.8 \pm 4.1^{\mathrm{a}}$ & $15.3 \pm 2.4$ & $18.8 \pm 5.0$ & $12.8 \pm 5.0$ \\
\hline Glucagon 8 days & $20.1 \pm 2.1^{b}$ & $15.3 \pm 3.0$ & $15.8 \pm 3.2$ & $10.7 \pm 3.2$ \\
\hline \multicolumn{5}{|l|}{ Diet $10 \%$ protein } \\
\hline Control & $26.7 \pm 4.2^{c}$ & $17.5 \pm 3.1^{\mathrm{d}, \mathrm{e}}$ & $19.3 \pm 3.3^{f}$ & $15.2 \pm 3.1^{9}$ \\
\hline Glucagon 4 days & $21.6 \pm 3.1$ & $12.9 \pm 2.9^{d}$ & $16.5 \pm 4.3^{f}$ & $12.9 \pm 2.1^{9}$ \\
\hline Glucagon 8 days & $19.7 \pm 5.3^{c}$ & $13.6 \pm 3.7^{\mathrm{e}}$ & $17.2 \pm 2.8$ & $13.6 \pm 5.2$ \\
\hline
\end{tabular}

$a-a, b-b, c-c, d-d, e-e, f-f, g-g$ Means with similar superscripts differ significantly $(P<0.05)$.

Table 5

Concentration of cholesterol ( $\bar{x} \pm S D$ ) in the liver and kidney ( $\mu \mathrm{mol} / \mathrm{g}$ tissue) of experimental and control mice maintained on diets with $10 \%$ and $16 \%$ of protein after glucagon injections

\begin{tabular}{|c|c|c|c|c|}
\hline \multirow[t]{2}{*}{ Group $(n=10)$} & \multicolumn{2}{|c|}{ Selected mice } & \multicolumn{2}{|c|}{ Unselected mice } \\
\hline & $\begin{array}{l}\text { Liver } \\
\overline{\mathrm{X}} \pm \mathrm{SD}\end{array}$ & $\begin{array}{c}\text { Kidney } \\
\overline{\mathrm{x}} \pm \mathrm{SD}\end{array}$ & $\begin{array}{l}\text { Liver } \\
\overline{\mathrm{x}} \pm S D\end{array}$ & $\begin{array}{l}\text { Kidney } \\
\overline{\mathrm{X}} \pm \mathrm{SD}\end{array}$ \\
\hline \multicolumn{5}{|l|}{ Diet $16 \%$ protein } \\
\hline Control & $4.1 \pm 0.7^{\mathrm{a}, \mathrm{b}}$ & $3.8 \pm 0.1^{d}$ & $4.5 \pm 1.4$ & $3.9 \pm 0.4$ \\
\hline Glucagon 4 days & $3.4 \pm 1.3^{\mathrm{a}}$ & $3.3 \pm 0.3$ & $4.6 \pm 0.5$ & $3.5 \pm 0.2$ \\
\hline Glucagon 8 days & $3.1 \pm 0.9^{b}$ & $3.1 \pm 0.9^{d}$ & $5.0 \pm 2.3$ & $3.7 \pm 0.9$ \\
\hline \multicolumn{5}{|l|}{ Diet $10 \%$ protein } \\
\hline Control & $4.9 \pm 1.9^{c, e}$ & $4.8 \pm 0.5^{f}$ & $3.9 \pm 1.7^{e}$ & $3.1 \pm 0.9^{f}$ \\
\hline Glucagon 4 days & $4.0 \pm 1.1^{c}$ & $4.5 \pm 2.1$ & $3.8 \pm 0.9$ & $2.9 \pm 0.4$ \\
\hline Glucagon 8 days & $4.5 \pm 0.8$ & $4.5 \pm 1.8$ & $3.5 \pm 0.7$ & $2.8 \pm 0.2$ \\
\hline
\end{tabular}

a-a,b-b,c,c,d-d-d,-e-e,f-f,g-g Means with similar superscripts differ significantly $(P<0.05)$.

However, it caused a significant reduction in the liver (16.5 vs. 19.3) and kidney (12.9 vs. 15.2) of animals kept on a low-protein diet (10\%) after administering glucagon over 4 days.

The injections of glucagon (Table 5) did not cause any significant differences in the concentration of cholesterol both in the liver and kidney of unselected mice, while the differences were significant in the liver of selected mice on a diet with $16 \%$ protein content, that were administered glucagon over 4 days (3.4 vs. 4.1) and 8 days (3.1 vs. 4.1 ) as well as in the kidney after 8 days (3.1 vs. 3.8). The administration of glucagon also lowered the level of cholesterol in the liver of selected mice on a diet with $10 \%$ protein content after 4 days (4.0 vs. 4.9).

\section{Discussion}

The adaptive processes of animals are always connected with the energy expenditure but this energy is immediately regenerated through the metabolic processes. By changing the rate of the metabolism, the organism can create a new system of homeostasis, e.g. by increasing the level of energy substrates in blood and using them at a higher rate. The energy management 
of the body is regulated by, among other things, glucagon (Filali-Zegzouti et al. 2000, 2005, Robson-Doucette et al. 2011). The mechanism of glucagon influencing fatty tissue adipocytes is known and it is closely associated with the system of receptor - adenyl cyclase - cAMP (Authier \& Desbuquois 2008, Shyangdan et al. 2011). The increase in the cAMP concentration occurs as well as the activation of the hormone-sensitive lipase, which as a consequence accelerates the decomposition of triacylglycerols. As a result of lipolysis, free fatty acids are released into the blood. The significant changes in the concentration of triacylglycerols observed in the liver and kidneys of the examined mice can be connected with these processes. After 4 and 8 days of injecting glucagon, a significant reduction of this indicator was observed in the liver of selected mice on a diet with $16 \%$ protein content as well as in the liver and kidneys of mice on a low-protein (10\% protein content) diet. A similar tendency of changes was observed in the liver and kidneys of unselected mice fed with low-protein feed after injecting glucagon over 4 days. This decrease in the concentration of triacylglycerols after administering glucagon observations could have been caused by its effect, i.e. the increase in the rate of their use in lipolysis processes, in 9 cases out of 16 possible.

Cholesterol is also an indicator widely discussed in the literature, among other reasons, because of its important physiological and biochemical functions in the body of animals and man organisms (Alam et al. 2011, Chien et al. 2008, Książek \& Konarzewski 2012). In the experiment described above, a statistically significant decrease in the cholesterol level was observed in the liver of selected mice that were administered glucagon over 4 and 8 days and kept on a diet with $16 \%$ protein content. The animals kept on a low-protein diet showed a decrease in the cholesterol level only in the liver after 4 days of injecting glucagon. The unselected mice did not show any significant changes of this indicator's level. The few cases where the cholesterol level was significantly decreased, only 4 out of 16 possible are probably an adaptive reaction to the excess of glucagon, in which it can be used for the synthesis of steroidal hormones in the adrenal cortex among others.

The data in Table 4 show that selection for fast rate of body weight gain led to a significant increase in the concentration of triacylglycerols in the liver and kidneys of mice kept on a diet with $16 \%$ protein content in comparison to the level of this indicator in unselected mice and in the liver and kidneys of animals kept on a low-protein diet ( $10 \%$ protein content). In turn, the concentration of cholesterol was significantly increased in the liver and kidney of selected mice fed only with low-protein feed in comparison to its level in unselected mice. This would mean that the selection influenced the concentration of triacylglycerols and cholesterol in the examined mice organs. It can be connected to storing lower amounts of reserve energy materials in the form of fat by the body of unselected animals and higher rate of their use in those animals during adaptive reactions.

Therefore, the results obtained would indicate the existence of differences in organism's reaction to the hormone and the diet that was applied in the two genetic groups that were examined. Higher resistance to glucagon was observed in unselected mice, in which the decrease of the change of concentration of triacylglycerols and cholesterol was significantly smaller in comparison to selected animals (in the liver of animals on a diet with $16 \%$ protein content).

The experimental factors used, which were introducing the excess of glucagon, diversification of a diet in regards to protein content and the selection turned out to be 
influencing the concentration of triacylglycerols and cholesterol in the liver and kidneys of the animals examined. It can be assumed that these changes were connected to the phenomenon of adaptation in the process of forming a new system of intracellular homeostasis caused by protein deficiency in the feed on one side and glucagon injections on the other.

\section{References}

Åberg J, Jansson G, Swenson JE, Mikusinski G (2000) Difficulties in detecting habitat selection by animals in generally suitable areas. Wildl Biol 6, 89-99

Alam N, Yoon KN, Lee TS (2011) Antihyperlipidemic activities of Pleurotus ferulae on biochemical and histological function in hypercholesterolemic rats. J Res Med Sci 16, 776-786

AOAC (2001) Official methods of analysis of AOAC International, Gaithersburg, MD, USA

Authier E, Desbuquois B (2008) Glucagon receptors. Cell Mol Life Sci 65, 1880-1899

Bateman N (1971) Selection of mice for growth on constant and on changing maize-milk diets. Anim Prod 13, $425-440$

Chien KL, Liau CS, Chen MF, Lee YT, Jeng JS, Hwang BS, Su TC (2008) Primary Hypercholesterolemia, Carotid Atherosclerosis and Insulin Resistance Among Chinese. Lipids 43, 117-124

Coleman J, Pierce KM, Berry DP, Brennan A, Horan B (2009) The influence of genetic selection and feed system on the reproductive performance of spring-calving dairy cows within future pasture-based production systems. J Dairy Sci 92, 5258-5269

Falconer DS (1960) Selection of mice for growth on high and low planes of nutrition. Genet Res 1, 91-113

Filali-Zegzouti Y, Abdelmelek H, Rouanet JL, Cottet-Emard JM, Pequignot JM, Barré H (2005) Role of catecholamines in glucagon-induced thermogenesis. J Neural Transm 112, 481-489

Filali-Zegzouti Y, Abdelmelek H, Rouanet JL, Cottet-Emard JM, Pequignot JM, Barré H (2000) Involvement of the catecholaminergic system in glucagon-induced thermogenesis in Muscovy ducklings (Cairina moschata). Pflügers Archiv 441, 275-280

Hancock AS, Du A, Liu J, Miller M, May CL (2010) Glucagon Deficiency Reduces Hepatic Glucose Production and Improves Glucose Tolerance In Adult Mice. Mol Endocrinol 24, 1605-1614

Klusek J, Klusek J, Kamińska A, Kołątaj A (2011) [ls cholesterol only an atherosclerosis?] Edukacja Biologiczna i Środowiskowa 39, 5-12 [in Polish]

Książek A, Konarzewski M (2012) Effect of Dietary Restriction on Immune Response of Laboratory Mice Divergently Selected for Basal Metabolic Rate. Physiol Biochem Zool 85, 51-61

Lou PH, Gustavsson N, Wang Y, Radda GK, Han W (2011) Increased Lipolysis and Energy Expenditure in a Mouse Model with Severely Impaired Glucagon Secretion. PLoS One 6, e26671

Peyot ML, Gray JP, Lamontagne J, Smith PJS, Holz GG, Murthy Madiraju SR, Prentki M, Heart E (2009) GlucagonLike Peptide-1 Induced Signaling and Insulin Secretion Do Not Drive Fuel and Energy Metabolism in Primary Rodent Pancreatic $\beta$-Cells. PLoS One 4, e6221

Robson-Doucette CA, Sultan S, Allister EM, Wikstrom JD, Koshkin V, Bhattacharjee A Prentice KJ, Sereda SB, Shirihai OS, Wheeler MB (2011) $\beta$-Cell Uncoupling Protein 2 Regulates Reactive Oxygen Species Production, Which Influences Both Insulin and Glucagon Secretion, Diabetes 60, 2710-2719

Shyangdan DS, Royle P, Clar C, Sharma P, Waugh N, Snaith A (2011) Glucagon-like peptide analogues for type 2 diabetes mellitus. Cochrane Database Syst Rev 5, e6423

Vieira E, Salehi E, Gylfe E (2007) Glucose inhibits glucagon secretion by a direct effect on mouse pancreatic alpha cells. Diabetologia 50, 370-379

Witek B, Ochwanowska E, Baranowska D, Kołątaj A (2007) The effect of selection for body weight on the activity of lysosomal enzymes in the liver and kidney of mice. Anim Sci Pap Rep 25, 119-125 